\title{
BIOEVALUATION OF THE ANTIMICROBIAL AND ANTI- PROLIFERATIVE POTENTIAL OF SOME DERIVATIVES OF 3,5-DINITRO-4-METHOXYAMINO-BENZOIC ACID
}

\author{
IRINA ZARAFU ${ }^{1}$, BIANCA PĂTRAȘCU ${ }^{1}$, LUMINIȚA MĂRUȚESCU ${ }^{2}$, CORALIA BLEOTU $^{3}$, \\ CARMEN LIMBAN ${ }^{4}$, ARNAUD TATIBOUËT $^{5}$, MARIANA CARMEN CHIFIRIUC ${ }^{2 *}$, DIANA \\ CAMELIA NUȚĂ ${ }^{4}$, PETRE IONIȚĂ ${ }^{1}$ \\ ${ }^{1}$ University of Bucharest, Faculty of Chemistry, Organic Chemistry, Biochemistry and Catalysis Department, $90-92$ Panduri \\ Road, Bucharest, Romania \\ ${ }^{2}$ University of Bucharest, Faculty of Biology and the Research Institute of the University of Bucharest, 91 -95 Splaiul \\ Independenței Street, Bucharest, Romania \\ 3 “Ștefan S. Nicolau” Institute of Virology, Cellular and Molecular Pathology Department, 285 Mihai Bravu Road, 030304, \\ Bucharest, Romania \\ 4 "Carol Davila" University of Medicine and Pharmacy, Faculty of Pharmacy, Pharmaceutical Chemistry Department, 6 \\ Traian Vuia Street, 020956, Bucharest, Romania \\ ${ }^{5}$ University of Orleans, ICOA-UMR7311, CNRS, France
}

*corresponding author: carmen.chifiriuc@gmail.com

Manuscript received: July 2019

\begin{abstract}
The purpose of this study was to evaluate the anti-proliferative and antimicrobial activity of some derivatives of 3,5-dinitro4-methoxyamino-benzoic acid previously obtained by coupling reactions of the above mentioned acid with benzylamine, $\mathrm{n}$ butylamine, 4-amino-antipyrine, benzocaine, 3,4-dimethyl-5-amino-isoxazole, 3,4-dimethoxyphenyl-2-ethylamine and the corresponding methyl ester. The anti-tumoural activity was investigated on HCT8 cells, while the antimicrobial one was tested on bacterial and fungal cells, in planktonic and adherent growth state. The obtained compounds exhibited good antimicrobial activity, both against free-living, planktonic, as well as biofilm embedded Gram-positive bacterial and fungal cells, as well as anti-proliferative activity on the HCT8 cells. While PZ2, PZ6 and PZ7 compounds have shown a remarkable effect against planktonic microbial cells, PZ4 and PZ7 proved to be the most active anti-biofilm compounds. Considering their anti-tumoural potential, PZ1 and PZ7 proved to be the most cytotoxic against the HCT8 cells, inducing the HCT8 cells apoptosis and arrest in the G2/M phase of the cellular cycle.
\end{abstract}

\section{Rezumat}

Scopul acestui studiu a fost evaluarea activității antimicrobiene și anti-proliferative a unor derivați ai acidului 3,5-dinitro-4metoxiamino-benzoic obținuți anterior prin reacții de cuplare ale acidului mai sus menționat cu benzilamina, $\mathrm{n}$-butilamina, 4 amino-antipirina, benzocaina, 3,4-dimetil-5-amino-isoxazolul, 3,4-dimetoxifenil-2-etilamina și esterul metilic corespunzător. Activitatea antitumorală a fost investigată pe celule HCT8, iar cea antimicrobiană față de celule bacteriene și fungice, în fază de creștere planctonică și aderată. Compușii obținuți au manifestat o bună activitate antimicrobiană, atât față de celulele bacteriene Gram-pozitive și fungice, aflate în suspensie, planctonice, precum și față de celulele încorporate în biofilm și de asemenea, au prezentat activitate anti-proliferativă față de celulele HCT8. În timp ce compușii PZ2, PZ6 și PZ7 au manifestat un efect deosebit față de celulele microbiene planctonice, PZ4 şi PZ7 s-au dovedit a fi citotoxici față de celulele HCT8, inducând apoptoza acestora și blocarea în faza G2/M a ciclului celular.

Keywords: derivatives of benzoic acid, antimicrobial activity, anti-biofilm, cellular cycle, cytotoxicity

\section{Introduction}

Alcoxy-aminyl persistent free radicals are a class of compounds discovered in the 60' and intensively studied due to their peculiar properties [1-6] such as their stability towards oxygen, lack of dimerization, as well as unusual physical and chemical properties (e.g.their intense colour that changes with $\mathrm{pH}$ ) [7]. The most well-known derivatives are of $\mathrm{N}$-alkoxyand N-picrylaminyls type and were studied mainly by means of electron spin resonance (ESR) and electronic absorption spectra [8-10]. These free radicals are stabilized by the capto-dative effect (Figure 1).

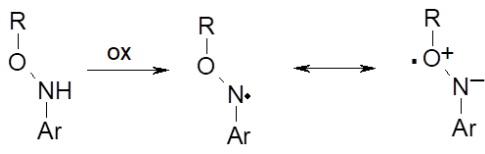

Figure 1.

Synthesis of alcoxy-aminyl free radicals and their resonance structure 
As a continuation of our previous work [3], we have used the previously synthesised eight derivatives of 3,5-dinitro-4-methoxyamino-benzoic acid (Figure 2), containing moieties with well-known biological effects (like phenazone (antipyrine) and benzocaine), for further biological characterization. Experimental and calculated hydrophobicity together with the total antioxidant capacity were measured before [3].<smiles>[R17]CCCNC(=O)c1cc([N+](=O)[O-])c(NOC)c([N+](=O)[O-])c1NCCCC</smiles>

Figure 2.

Structure of the compounds employed in this study (denoted as PZ0-PZ7)

\section{Materials and Methods}

\section{Antimicrobial activity assays}

The antimicrobial activity of the obtained materials was tested against bacterial and fungal reference strains, traceable to the American Type Culture Collection (ATCC), i.e. Gram-negative (Escherichia coli ATCC 8739, Pseudomonas aeruginosa ATCC 27853) and Gram-positive (Staphylococcus aureus ATCC 6538, Enterococcus faecium ATCC 29212) bacterial and one yeast strain (Candida albicans ATCC 10231). The respective strains were streaked on tryptic soy agar and incubated for 15 to $18 \mathrm{~h}$ at $37^{\circ} \mathrm{C}$. From the fresh cultures, microbial suspensions of $1.5 \times 10^{8} \mathrm{CFU} / \mathrm{mL}$ density (corresponding to $0.5 \mathrm{McFarland}$ turbidimetric standard) were prepared in sterile saline and further used for the antimicrobial assays. The compounds were suspended in DMSO to prepare a stock solution of $10 \mathrm{mg} / \mathrm{mL}$ concentration. The quantitative assay of the antimicrobial activity was performed by liquid medium micro-dilution method in 96 multi-well plates. Briefly, binary dilutions ranging from $5000 \mu \mathrm{g} / \mathrm{mL}$ to $9.76 \mu \mathrm{g} / \mathrm{mL}$ from the tested compounds, as well as binary dilutions from the reference antibiotic (ticarcillin) and antifungal (fluconazole) drug in the range recommended by the CLSI (Clinical Laboratory Standards Institute) were performed in a total volume of $200 \mu \mathrm{L}$ Muller Hinton broth. The wells were then seeded with a fix volume of $50 \mu \mathrm{L}$ of the microbial suspensions. Positive and negative controls (culture medium seeded with the microbial suspensions and sterile culture medium, respectively) were used in the experiment. The plates were incubated at $37^{\circ} \mathrm{C}$ for $24 \mathrm{~h}$ and then, the absorbance of the wells liquid content was measured at $600 \mathrm{~nm}$ (Apollo LB 911
ELISA plate reader). The MIC (minimal inhibitory concentration) was considered as the lowest concentration of the tested compound that induced an inhibition of the microbial growth corresponding to an absorbance value inferior to that of the positive control used in the experiment [11-14]. In order to evaluate the influence of the tested suspensions on the ability of microbial strains to colonize the inert substratum, a microtiter plate method was used. In this purpose, the micro-plates used for the MIC assay were emptied and washed three times by phosphate buffered saline. The biofilm formed on the plastic wells wall was fixed for 5 min with cold methanol, coloured for $15 \mathrm{~min}$ with a violet crystal solution and then re-suspended in a $33 \%$ acetic acid solution. The optical density of the coloured suspension was quantified by measuring the absorbance at $490 \mathrm{~nm}$. The minimal biofilm eradication concentration (MBEC) values were considered as the lowest concentration of the tested compound that induced an inhibition of microbial adherence and biofilm development on the plastic wells, revealed by a decrease of the absorbance value in comparison with the positive control used in the experiment $[12,15]$. Anti-proliferative activity

For the cell viability assay, HCT8 cells were seeded at a density of $10^{4}$ cells/well in 96-well plates and maintained in DMEM: F12 supplemented with $10 \%$ foetal bovine serum. The treatment was performed with different concentrations and quantified after 24 hours using CellTiter Assay (Promega) according to the manufacturer's indications. The results were presented as percentage of viable cells from the untreated cells. For cell morphology evaluation, treated cells were fixed in ethanol and stained with propidium iodide for 5 minutes. 
For the cell cycle assay HCT8 cells were seeded at a density of $10^{5}$ cells $/ \mathrm{cm}^{2}$ in 24-well plates and treated with $5 \mu \mathrm{g} / \mathrm{mL}$ of the tested compounds. After 24 hours of treatment the cells were detached with trypsin, fixed in could $70 \%$ ethanol and stained with RNA se/propidium iodide for 2 hours. Reading was done using Beckman Coulter flow cytometer and data analysis using FlowJo software [16].

\section{Results and Discussion}

\section{Antimicrobial activity}

The antimicrobial activity of the obtained compounds was assessed by quantitative methods on planktonic microbial cells (MIC assay) and biofilm-embedded bacteria (MBEC assay). Concerning the activity of the tested compounds against planktonic cells, the most active compounds proved to be PZ2, PZ6 and PZ7, which exhibited very low MIC values against all five tested strains $(9.76-39 \mu \mathrm{g} / \mathrm{mL})$, followed by PZ3 exhibiting a very low MIC value of $9.76 \mu \mathrm{g} / \mathrm{mL}, \mathrm{PZ} 4$ with MIC values of $9.76-19.5 \mu \mathrm{g} / \mathrm{mL}$ and PZ0 with MIC values of $9.76-39 \mu \mathrm{g} / \mathrm{mL}$ against four of the five microbial strains, excepting $P$. aeruginosa, well known for its high intrinsic and acquired resistance to numerous antimicrobial compounds (Table I). The narrowest spectrum of antimicrobial activity was exhibited by the compounds PZ1 and PZ5 exhibiting low MIC values only against two of the five tested microbial strains, i.e., S. aureus and E. faecium for PZ1 and E. coli and C. albicans for PZ5 (Table I). For two strains, i.e. P. aeruginosa and E. faecium the efficiency of some of the tested compounds reference was superior that of the reference antibiotic (ticarcillin).

The MIC ( $\mu \mathrm{g} / \mathrm{mL})$ values of the tested compounds against the tested microbial strain

\begin{tabular}{cccccc}
\hline & E. coli & P. aeruginosa & S. aureus & E. faecium & C. albicans \\
\hline PZ0 & $\mathbf{9 . 7 6}$ & 1250 & $\mathbf{3 9}$ & $\mathbf{1 9 . 5}$ & $\mathbf{9 . 7 6}$ \\
PZ1 & 5000.00 & 156 & $\mathbf{9 . 7 6}$ & $\mathbf{9 . 7 6}$ & 5000.00 \\
PZ2 & $\mathbf{9 . 7 6}$ & $\mathbf{3 9 . 0 0}$ & $\mathbf{9 . 7 6}$ & $\mathbf{9 . 7 6}$ & $\mathbf{9 . 7 6}$ \\
PZ3 & $\mathbf{9 . 7 6}$ & 5000.00 & $\mathbf{9 . 7 6}$ & $\mathbf{9 . 7 6}$ & $\mathbf{9 . 7 6}$ \\
PZ4 & $\mathbf{1 9 . 5 0}$ & 5000.00 & $\mathbf{9 . 7 6}$ & $\mathbf{9 . 7 6}$ & $\mathbf{9 . 7 6}$ \\
PZ5 & $\mathbf{3 9 . 0 0}$ & 5000 & 5000 & 5000 & $\mathbf{9 . 7 6}$ \\
PZ6 & $\mathbf{3 9 . 0 0}$ & $\mathbf{9 . 7 6}$ & $\mathbf{9 . 7 6}$ & $\mathbf{9 . 7 6}$ & $\mathbf{9 . 7 6}$ \\
PZ7 & $\mathbf{3 9 . 0 0}$ & $\mathbf{9 . 7 6}$ & $\mathbf{9 . 7 6}$ & $\mathbf{9 . 7 6}$ & $\mathbf{9 . 7 6}$ \\
Reference antibiotic (ticarcillin) & $\mathbf{1 6}$ & $\mathbf{1 6}$ & $\mathbf{8}$ & $\mathbf{3 2}$ & \\
Reference antifungal (fluconazole) & & & & & $\mathbf{2}$ \\
\hline
\end{tabular}

The most susceptible strains growing in planktonic state proved to be $C$. albicans and the Gram-positive cocci E. faecium and $S$. aureus, while the most resistant was $P$. aeruginosa.

The higher efficiency of the tested compound against fungal and Gram-positive bacterial cells could be explained by the differences in their cell wall structure. In the case of Gram-negative bacteria, the antimicrobial compounds should surpass an additional barrier, represented by the outer membrane, rich in lipopolysaccharides. The outer membrane can be crossed at porin levels, but the ability to transfer through these channels depends on the size, charge and shape of the antimicrobial substance. Moreover, efflux pumps may also be more prevalent in the Gram- negative cell walls, preventing the intracellular accumulation of the antimicrobial substance at active concentrations. Biofilm-growing bacteria are generally much more resistant than their planktonic counterparts, due to their multiple genetic and biochemical properties, such as production of an extracellular polymeric matrix, acting as a physical and chemical barrier, inhibiting or delaying the penetration of antibiotics, slow growing or starvation metabolic state of some biofilm cells, genetic adaptation by increasing the mutation rate, phenotypic differentiation inside biofilm etc. These results demonstrate the acute necessity of finding compounds that could inhibit, disrupt or eradicate microbial biofilms, such as enzymes, sodium salts, metal nanoparticles, acids, chitosan derivatives, or plant extracts and to elucidate the mechanisms of their antibiofilm activity [17]. Also, it has been demonstrated that some currently used antibiotics, such as quinolones could penetrated the microbial biofilms [18].

In our study, the comparative analysis of the efficiency of the obtained compounds against planktonic cells grown in liquid media and biofilm cells revealed a different behaviour depending on tested microbial strain (Figure 3).

All tested compounds strongly inhibited the E. faecium and $C$. albicans biofilm development, with very low MBEC values of $9.76 \mu \mathrm{g} / \mathrm{mL}$. The biofilm formed by $S$. aureus was inhibited by six compounds with low MBEC values ranging from 9.76 to $19.5 \mu \mathrm{g} / \mathrm{mL}$ and $P$. aeruginosa by four compounds (MIC of $9.76 \mu \mathrm{g} / \mathrm{mL}$ ). The biofilm formed by $E$. coli was very recalcitrant, even to high concentrations of the tested compounds, the MBEC values being more than hundred times higher than the MIC in some cases (Table II). For $P$. aeruginosa, $S$. aureus, E. faecium and $C$. albicans strains, the MBEC values were lower than for the reference antibiotic and antifungal, respectively. 
Table II

The MBEC $(\mu \mathrm{g} / \mathrm{mL})$ values of the tested compounds against the tested microbial strains

\begin{tabular}{cccccc}
\hline & E. coli & P. aeruginosa & S. aureus & E. faecium & C. albicans \\
\hline PZ1 & 156.25 & 625 & $\mathbf{3 9}$ & $\mathbf{9 . 7 6}$ & $\mathbf{9 . 7 6}$ \\
PZ1 & 1250.00 & 625 & $\mathbf{9 . 7 6}$ & $\mathbf{9 . 7 6}$ & $\mathbf{9 . 7 6}$ \\
PZ2 & 1250 & $\mathbf{9 . 7 6}$ & 156.25 & $\mathbf{9 . 7 6}$ & $\mathbf{9 . 7 6}$ \\
PZ3 & 2500 & 1250.00 & $\mathbf{9 . 7 6}$ & $\mathbf{9 . 7 6}$ & $\mathbf{9 . 7 6}$ \\
PZ4 & 635.00 & $\mathbf{9 . 7 6}$ & $\mathbf{1 9 . 5 3}$ & $\mathbf{9 . 7 6}$ & $\mathbf{9 . 7 6}$ \\
PZ5 & 5000.00 & $\mathbf{9 . 7 6}$ & 2500 & $\mathbf{9 . 7 6}$ & $\mathbf{9 . 7 6}$ \\
PZ6 & 156.25 & 156.25 & $\mathbf{9 . 7 6}$ & $\mathbf{9 . 7 6}$ & $\mathbf{9 . 7 6}$ \\
PZ7 & 2500.00 & $\mathbf{9 . 7 6}$ & $\mathbf{9 . 7 6}$ & $\mathbf{9 . 7 6}$ & $\mathbf{9 . 7 6}$ \\
Reference antibiotic (ticarcillin) & 2500.00 & 156.25 & $\mathbf{3 9 . 0 6}$ & 156.25 & \\
Reference antifungal (fluconazole) & & & & & $\mathbf{1 9 . 5 3}$ \\
\hline
\end{tabular}
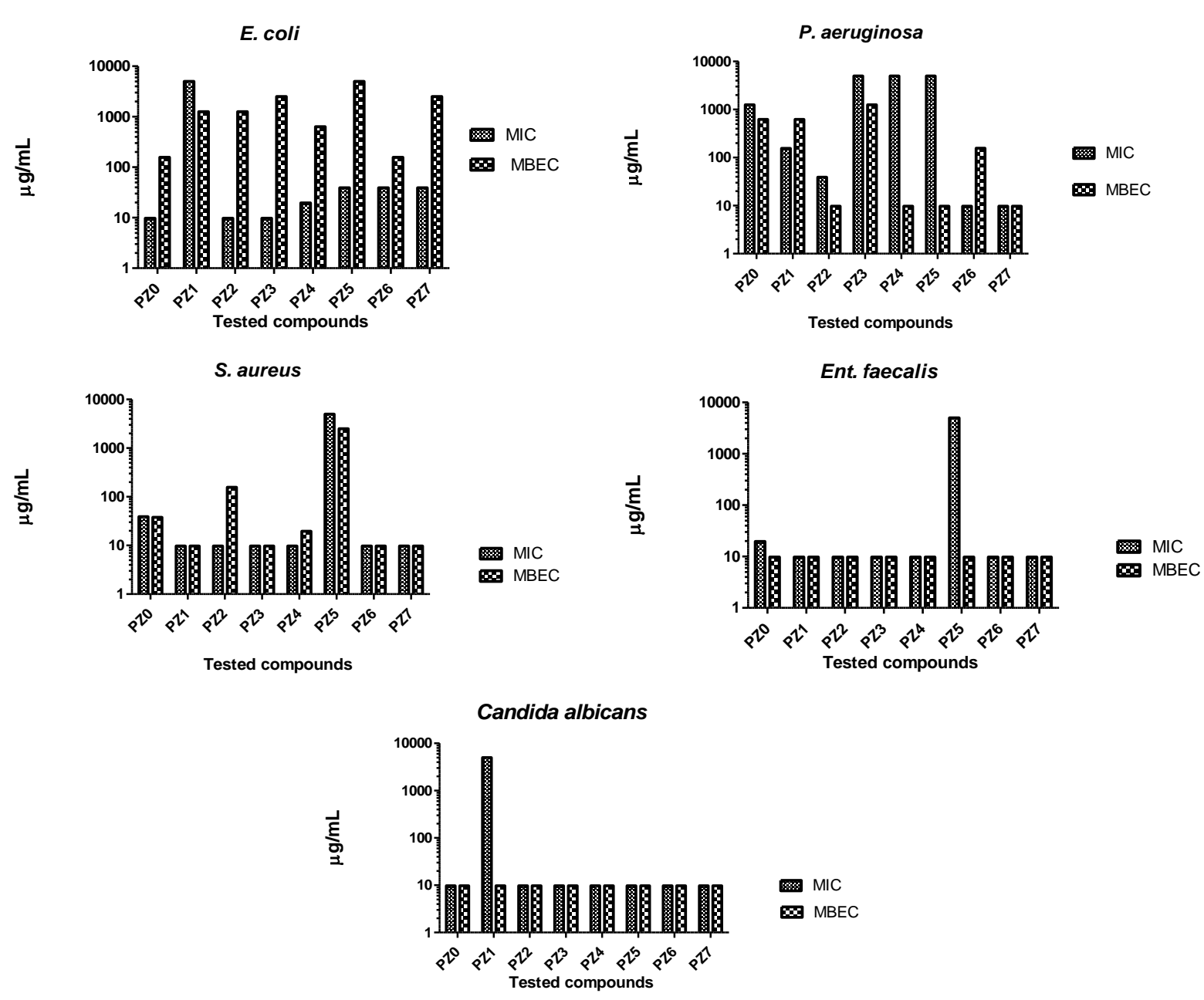

Figure 3.

Comparative evaluation of the efficiency of the tested compounds against planktonic and biofilm-embedded cells

In the case of $E$. coli biofilm, all tested compounds excepting PZ1 exhibited a much lower efficiency against biofilm - embedded cells. In case of $P$. aeruginosa biofilm, PZ1 was less efficient; PZ7 exhibited the same efficiency, while PZ0, PZ2, PZ3, PZ4 and PZ5 proved to exhibit an improved activity against biofilm-embedded cells as compared to planktonic ones. This is significant, taking into account that $P$. aeruginosa is the second most commonly encountered human pathogen isolated from different hospital acquired infections surgical sites, chronic and burn wounds) and is the most frequent Gram-negative etiologic agent of medical devices biofilm associated infections [16]. In case of $S$. aureus biofilm, PZ0, PZ1, PZ3, PZ6 and PZ7 exhibited the same efficiency; $\mathrm{PZ} 2$ and PZ4 were less efficient, while PZ5 proved to be more efficient than against the planktonic cells. In case of E. faecium and C. albicans strains, the majority of the tested compounds exhibited similar efficiencies against planktonic and biofilm cells, excepting PZ0 and PZ5 for E. faecium and PZ1 for C. albicans, which exhibited a higher efficiency on biofilm-embedded, as 
compared to planktonic cells. Remarkably, the PZ5 compound proved improved anti-biofilm efficiency against a wide spectrum of microbial strains, including three of the most important etiological agents of hospital-acquired infections, i.e. P. aeruginosa, $S$. aureus and E. faecium.

Taken together, the obtained results demonstrated that despite the fact that the MBEC values were in some cases, as expected, higher than the MIC ones, however the tested compounds have shown a similar or even a more intense anti-biofilm activity, these results being promising for the potential use of these compounds to enrich the armamentarium of antimicrobial agents efficient in biofilm associated infections (Figure 3). Anti-proliferative activity

Among the analysed substances, PZ0 was the least toxic. Also, a lower toxicity was observed for PZ5. In contrast, PZ1 and PZ7 were the most toxic (Figure 4). HCT8 cells morphology has been changed depending on the tested compound. Compounds PZ1-PZ7 reduced the number of viable, adherent cells. Particularly, in the case of PZ1 and PZ7, cells with small non-uniform and intensely stained nucleus were observed (Figure 5), suggesting apoptosis.

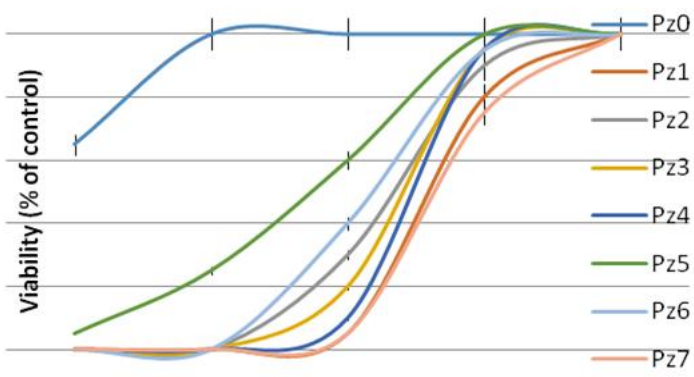

Figure 4.

The effects of the compounds PZ1-PZ7on HCT8 cells
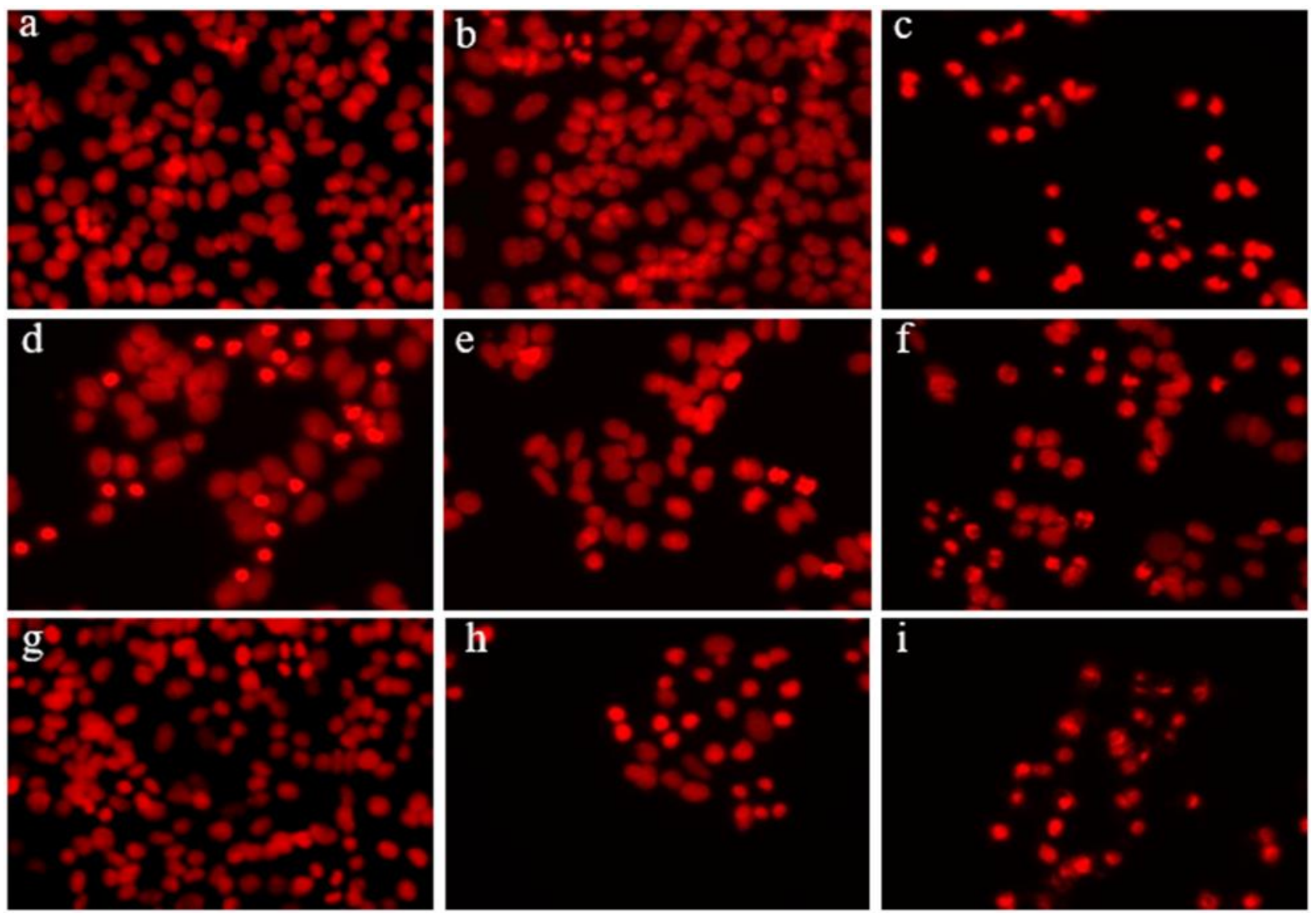

Figure 5.

The effects of $5 \mu \mathrm{g} / \mathrm{mL}$ compounds PZ1-PZ7 on HCT8 cells morphology

(adherent cells stained with propidium iodide, 630x) (a) untreated HCT8 cells; (b) PZ0 treated; (c) PZ1 treated; (d) PZ2 treated; (e) PZ3 treated; (f) PZ4 treated; (g) PZ5 treated; (h) PZ6 treated; (i) PZ7 treated

The cell cycle analysis showed that PZ1, PZ6 and PZ7 have an increased toxicity, demonstrated by the occurrence of a sub-G0 peak, on the left of G1. In addition, these substances block the cell cycle in G2/M, suggesting that they could be used as anti-tumour cytostatic drugs (Figure 6) [19].

Compounds PZ1 and PZ7 contain an ester group that can easily hydrolyse under physiologic condition; 
FARMACIA, 2020, Vol. 68, 1

moreover, PZ7 can be considered a benzocaine derivative, known for its medical use [20, 21].

The antimicrobial effects of benzoic acid derivatives [22] or carboxylate ligands [23] against biofilms are well documented in literature; therefore the continuous search for modern antimicrobials, including methoxyamino moieties, is still a topic of high interest [24-27].
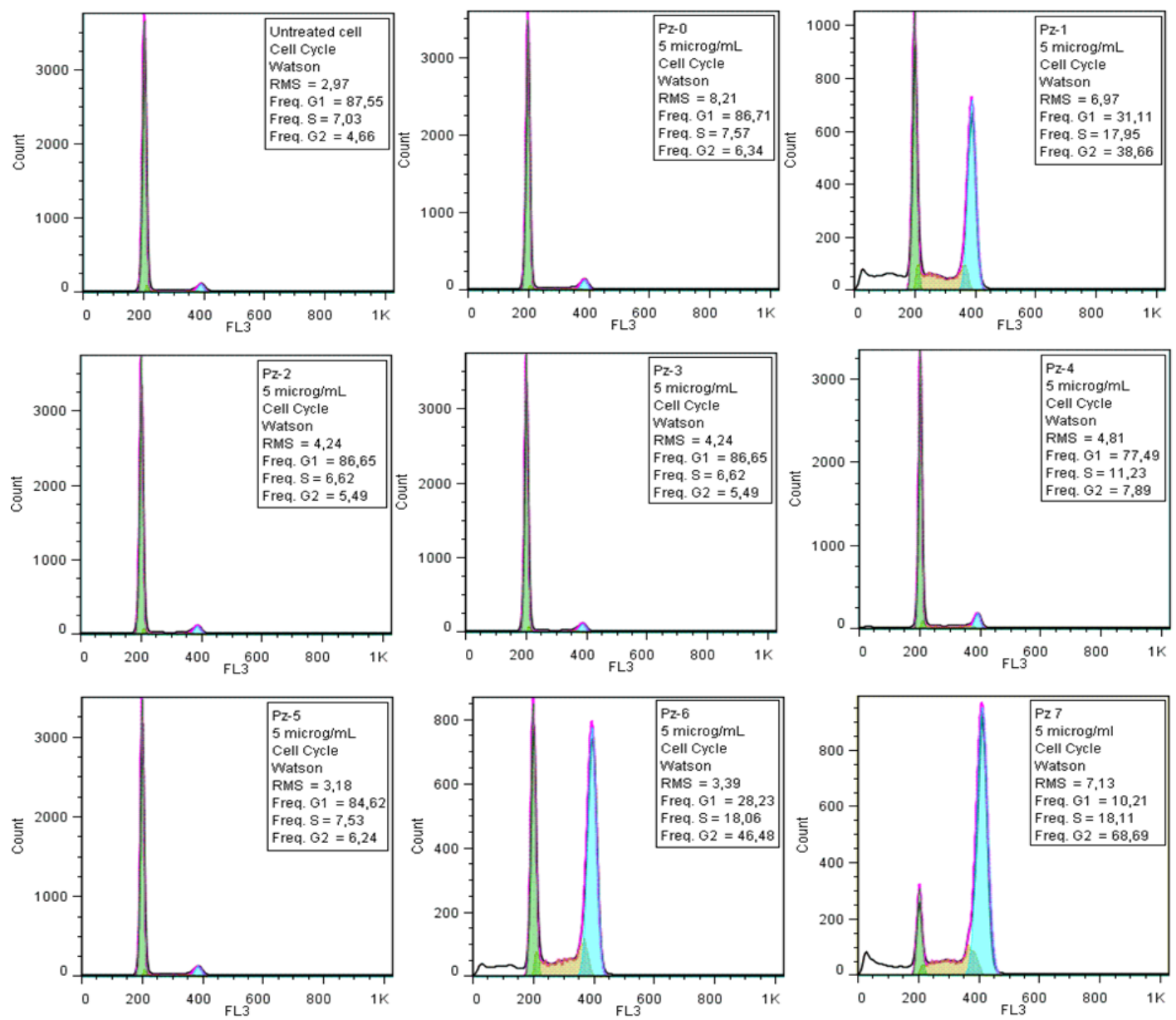

Figure 6.

Influence of the studied compounds on the cellular cycle of HCT8 cells assessed by flow cytometry

\section{Conclusions}

The results of the antimicrobial activity assay show that the tested compounds exhibited good antimicrobial activity, particularly against Gram-positive bacterial and fungal cells. While PZ2, PZ6 and PZ7 compounds have shown a remarkable effect against planktonic microbial cells, PZ4 and PZ7 proved to be the most active anti-biofilm compounds. Considering their anti-tumoral potential, PZ1 and PZ7 proved to be the most cytotoxic against the HCT8 cells, inducing their apoptosis and arrest in the G2/M cell cycle phase.

\section{Acknowledgement}

This work was financially supported by "Carol Davila" University of Medicine and Pharmacy through Contract no. 23PFE/17.10.2018 funded by the Ministry of Research and Innovation within PNCDI III, Program 1 - Development of the National RD system, Subprogram 1.2 - Institutional Performance RDI excellence funding projects.

\section{Conflict of interest}

The authors declare no conflict of interest.

\section{References}

1. Balaban AT, Frangopol PT, Frangopol M, Negoita N, Stability and equilibria of free radicals - III: Preparation of stable, sterically shielded, diarylnitrogen radicals with donor and acceptor aryl groups in the same molecule. Tetrahedron, 1967; 23(12): 4661-4676.

2. Balaban AT, Frangopol M, Negoita N, Frangopol PT, Paraschiv M, Factors affecting stability and equilibria of free radicals. V. Synthesis and spectra of polynitrophenyl-alkoxy-amines. Rev Roum Chim, 1969; 14: 941-945.

3. Bem M, Baratoiu R, Radutiu C, Lete C, Mocanu S, Ionita G, Lupu S, Caproiu MT, Madalan AM, Patrascu B, Zarafu I, Ionita P, Synthesis and structural characterization of some novel methoxyamino 
derivatives with acid-base and redox behavior. $J$ Molec Struct., 2018; 1173: 291-299.

4. Covaci IC, Constantinescu T, Caproiu MT, Draghici C, Ionita P, Luca C, Stanciuc G, Maganu M, Balaban AT, 3,5-Dinitro-4-methoxyaminobenzoic acid and its derivatives. Rev Roum Chem., 1999; 44: 333-340.

5. Covaci IC, Ionita P, Caproiu MT, Socoteanu R, Constantinescu T, Balaban AT, 1,3-bis(2,4,6trinitrophenylaminooxy)propane and its 4-cyano2,6-dinitrophenyl congener: Synthesis and properties.Cent Eur J Chem., 2003; 1: 53-64.

6. Negoita N, Baican R, Balaban AT, N-(2,4,6tricarbomethoxyphenyl)-alkoxyaminyls, new pushpull stable nitrogen free radicals. Tetrah Lett., 1973; 14(21): 1877-1878.

7. Tudose M, Badea FD, Ionita G, Maganu M, Caproiu MT, Ionita P, Constantinescu T, Balaban AT, NAlkoxy-3,5-dinitro-4-aminobenzoic acid derivatives with controlled physico-chemical properties. Struct Chem., 2010; 21(6): 1227-1234.

8. Stanciuc G, Caproiu MT, Caragheorgheopol A, Caldararu H, Balaban AT, Walter RI, Factors affecting stability and equilibria of free radicals. XII. N-Alkoxypicrylamines and ESR spectra of the corresponding capto-dative persistent aminyls. $J$ Magn Reson., 1987; 75: 63-72.

9. Stanciuc G, Caproiu MT, Caldararu H, Caragheorgheopol A, Constantinescu T, Balaban AT, Factors affecting stability and equilibria of free radicals. XVI. Preparation and EPR spectra of capto-dative Nalkoxy-dinitrophenyl-aminyls. Rev Roum Chim., 1989; 34: 1895-1905.

10. Stanciuc G, Caproiu MT, Caldararu H, Caragheorgheopol AT, Constantinescu Balaban AT, Factors affecting stability and equilibria of free radicals. XV. EPR evidence of formation of $\mathrm{N}$-alkoxypicramides on oxidation of $\mathrm{N}$-alkoxy-dinitroanilines. Electronic structure of aminyl radicals. Z Naturforsch., 1989; 44b: 1459-1463.

11. Guta R, Limban C, Missir AV, Caproiu MT, Nuta DC, Andreescu DN, New potential antimicrobial agents from 2-methoxy-)-O-acyl-oximino-dibenz[b,e]oxepin class. Rev Chim (Bucharest), 2011; 62: 606-609.

12. Limban C, Missir AV, Nuta DC, Caproiu MT, Papacocea MT, Chirita C, Synthesis of some new 2((4-chlorophenoxy)methyl)-N-(arylcarbamothioyl) benzamides as potential antifungal agents. Farmacia, 2016; 64(5): 775-779.

13. Nuță DC, Măruțescu L, Missir AV, Morusciag L, Chirita C, Curutiu C, Badiceanu CD, Toma PM, Limban $\mathrm{C}$, In vitro evaluation of the antimicrobial activity of N-phenylcarbamothioyl benzamides against planktonic and adherent microbial cells. Rom Biotech Lett., 2017; 22(6): 13163- 13168.

14. Nuţă DC, Chifiriuc MC, Missir AV, Chiriţă IC, Bădiceanu $\mathrm{CD}$, In vitro evaluation of the antibacterial and antifungal activity of some new N-(2dialkylaminoethyl) benzanilides. Farmacia, 2010; 58(1): 38-45

15. Limban C, Missir AV, Grumezescu AM, Oprea AE, Grumezescu V, Vasile BS, Socol G, Trusca R, Caproiu MT, Chifiriuc MC, Gălăteanu B, Costache M, Morușciag L, Pîrcălăbioru G, Nuță DC, Bioevaluation of novel anti-biofilm coatings based on $\mathrm{PVP} / \mathrm{Fe}_{3} \mathrm{O}_{4}$ nanostructures and 2-((4-ethylphenoxy)methyl)-N(arylcarbamothioyl) benzamides. Molecules, 2014; 19(8): 12011-12030.

16. Janković A, Eraković S, Ristoscu C, Mihailescu Serban N, Duta L, Visan A, Stan GE, Popa AC, Husanu MA, Luculescu CR, Srdić VV, Janaćković DJ, Mišković-Stanković V, Bleotu C, Chifiriuc MC, Mihailescu IN, Structural and biological evaluation of lignin addition to simple and silver-doped hydroxyapatite thin films synthesized by matrixassisted pulsed laser evaporation. J Mater Sci Mater Med., 2015; 26(1): 5333: 1-14.

17. Taraszkiewicz A, Fila G, Grinholc M, Nakonieczna J, Innovative Strategies to Overcome Biofilm Resistance. Bio Med Res Int., 2013; 2013: 150653: 1-13.

18. Gupta K, Liao J, Petrova OE, Cherny KE, Sauer K, Elevated levels of the second messenger c-di-GMP contribute to antimicrobial resistance of Pseudomonas aeruginosa. Mol Microbiol., 2014; 92(3): 488-506.

19. Zarafu I, Olar R, Chifiriuc MC, Bleotu C, Ionita P, Multescu M, Ionita G, Gradisteanu G, Tatibouet A, Badea M. Synthesis, thermal, spectral, antimicrobial and cytotoxicity profile of the Schiff bases bearing pyrazolone moiety and their $\mathrm{Cu}(\mathrm{II})$ complexes. $J$ Therm Anal Calorim., 2018; 134(3): 1851-1861.

20. Paun A, Zarafu I, Caproiu MT, Draghici C, Maganu M, Cotar AI, Chifiriuc MC, Ionita P, Synthesis and microbiological evaluation of several benzocaine derivatives. Comptes Rendus Chimie, 2013; 16(7): 665-671.

21. Nuță DC, Chifiriuc MC, Draghici C, Limban C, Missir AV, Murusciag L, Synthesys, characterization and antimicrobial activity evaluation of new agents from benzamides class. Farmacia, 2013; 61(5): 966-974.

22. Sullivan DJ, Azlin-Hasim S, Cruz-Romero M, Cummins E, Kerry JP, Morris MA, Antimicrobial effect of benzoic and sorbic acid salts and nano-solubilisates against Staphylococcus aureus, Pseudomonas fluorescens and chicken microbiota biofilms. Food Control, 2020; 107: 106786: 1-7.

23. Sirajuddin M, Ali S, McKee V, Matin, A, Synthesis, characterization and biological screenings of 5coordinated Organotin (IV) complexes based on carboxylate ligand. J Molec Struct., 2020: 1207: 127683.

24. Anurova MN, Bakhrushina EO, Demina NB, Panteleeva E.S, Modern Preservatives of Microbiological Stability. Pharm Chem J., 2019; 53(6): 564-571.

25. Bose S, Hodgson DRW, Stereoselective Syntheses of 3'-Hydroxyamino-and 3'-Methoxyamino-2',3'Dideoxynucleosides. Org Let., 2019; 21(22): 90849088.

26. Pânzariu A, Vasincu IM, Dragostin OM, Drăgan M, Buron F, Routier S, Profire L, New arginine derivativessynthesis and biological evaluation. Farmacia, 2015; 63(4): 581-585.

27. Topală T, Bodoki AE, Hangan A, Gheorghe CS, Oprean L, Revisiting therapeutic sulfonamides in the attempt to improve the antimicrobial properties through metal-ion coordination. Farmacia, 2019; 67(5): 749-758. 